\title{
ECOLINGUISTIC APPROACH \\ TO THE TRAINING OF STUDENTS-PHILOLOGISTS
}

\section{ЭКОЛИНГВИСТИЧЕСКИЙ ПОДХОД \\ К ОБУЧЕНИЮ СТУДЕНТОВ-ФИЛОЛОГОВ}

\section{Pasynok Valentyna ${ }^{1}$}

DOI: http://dx.doi.org/10.30525/978-9934-571-27-5_38

Abstract. The most important aspects of formation of the student's personality - competence, professionalism, creative approach, creativity of professional philologist- are comprehended in the article. Levels of communicative competence - linguistic speech, discoursive, cultural, and rhetorical as well as basic parts of communicative competence- are singled out. Professional activity is connected with communicative competence, creativity and dialogism. Professionalism is the property of people to perform their professional activities competently, creatively, effectively.

The task of the higher school is to prepare a specialist for future professional activity and for successful functioning in the dynamic conditions of the present. In this regard, pedagogical problems of formation of communicative competence of the individual are the priority in Ukrainian society. When preparing today's philologist, the most important role is played by a foreign language, because it is the means of international communication that can expand and realize all aspects of the professional activity of a modern specialist. Foreign language in the university promotes development of communicative, informational, sociocultural and other competences. Training of linguists in the system of higher professional education should help them to develop such abilities that will enable them to use a foreign language as an instrument of communication in the dialogue of cultures in their professional activities.

Methodological bias of this investigation includes two problems: how a person influences language and how language influences a person, his thinking and culture. The article discusses urgent issues of the aspect "Home

\footnotetext{
${ }^{1}$ Doctor of Pedagogical Sciences, Professor, Academician of the National Academy of Educational Sciences of Ukraine, V.N. Karazin Kharkiv National University, Ukraine
} 


\section{Ecolinguistic approach to the training of students-philologists}

Reading" at the French language classes at the university. It describes forms of tasks and exercises that facilitate involvement of junior and senior students in the process of reading foreign literature in the original. Attention is given to types of extensive study and analysis of the text. Interpretation of a foreign language text includes the following stages: exposure, analytical-evaluation, analytical-linguistic and creative interpretation. The article addresses the content of these stages and corresponding forms of tasks. That assumes a versatile and multi-faceted personality-oriented approach both from the student and from the teacher: skills of extracting information from the authentic text, use of various learning strategies for in-depth analysis, special technology of teaching in the form of teaching assignments, exercises and methods of control.

\section{1. Вступление}

Во второй половине XX ст. вопрос о трактовке понятия профессионализм выходит на новый уровень и характеризуется концептуальным подходом - он включает важнейшие компоненты успешной профессиональной деятельности: компетентностный и креативный подходы к будущей профессии. Профессионализм - это свойство людей компетентно, творчески, эффективно выполнять свою профессиональную деятельность.

Как справедливо отмечает К.Ф. Седов, «профессионализм - высокое мастерство, глубокое овладение профессией, качественное, профессиональное исполнение. Это - также талант вкладывать душу в то, что ты делаешь здесь и сейчас. Профессионализм - это высокий уровень мастерства человека, позволяющий ему добиться успеха в выбранном деле. Профессионализм - это умение трезво оценить фронт работы и рационально распределить свои силы для их выполнения. Профессионализм - это знание всех тонкостей и деталей своей профессии и бесконечный действенный интерес к ней. Профессионализм - это личная философия успеха» [1, с. 56-58].

Таким образом, профессиональная деятельность предполагает высокую компетентность, основанную на творческих решениях. Это - процесс, осуществляемый в разных типах дискурса - политическом, юридическом, научном, педагогическом и др. В.А. Самохина считает, что деятельность преподавателя вуза предполагает профессиональный подход к учебному и научному процессу, строяще- 


\section{Pasynok Valentyna}

муся на принципе диалогизма, который предоставляет возможность студентам свободной диалогической самореализации в общении с преподавателем, а также с миром культуры и самим собой... Диалогическое общение - это наилучшая форма общения - это открытые, доверительные отношения в обучении..,, основным принципом которого является инновационный процесс - изменение в стиле мышления преподавателя,...готовность к контакту и сотрудничеству, активный отклик на проблемные ситуации, готовность к конструктивному обоснованию различных точек зрения, взаимное решение вопросов. Такой новый тип общения предполагает мышление соавторства, со-знания и самопознания» [2, с. 147-149].

В.А. Кан-Калик выделил следующие профессиональные особенности педагога:дискурсивный коммуникативный компетентность интерактивность

1.Творческие элементы присутствуют во всех сферах педагогической деятельности, хотя в педагогическом труде и функционирует определенная совокупность приемов и навыков, которым он обучается. Но применяются эти приемы и навыки в постоянно изменяющихся, нестандартных ситуациях. В этом своеобразном взаимодействии сформированных приемов и навыков деятельности и не стоящей на месте, развивающейся структуры образовательного процесса с постоянно изменяющимися педагогическими ситуациями, требующими применения скорректированных и модифицированных приемов и навыков, заключается специфика педагогического творчества.

2.Сопряженность творческого процесса педагога с творческим процессом каждого учащегося и всего преподавательского коллектива. Без сотворчества воспитанника и без координации творческих усилий педагога с коллективным творчеством педагогическое творчество невозможно.

3. Большая и постоянная часть творческого процесса педагога осуществляется на людях, в обстановке публичной деятельности, что также накладывает неизбежный отпечаток на специфику протекания самого творческого процесса и предъявляет определенные требования к личности педагога. Такой характер педагогического творчества требует от преподавателя максимально управлять своими психическими состояниями, оперативно вызывать творческое самочувствие у самого себя и у студентов [3, с. 9-10]. 


\section{Ecolinguistic approach to the training of students-philologists}

Задача высшей школы - подготовить специалиста к будущей профессиональной деятельности и к успешному функционированию в динамических условиях современности. В связи с этим, педагогические проблемы становления коммуникативной компетентности личности являются приоритетными в украинском обществе. При подготовке сегодняшнего филолога важнейшую роль играет иностранный язык, потому что именно он является средством международного общения, способным расширить и реализовать все аспекты профессиональной деятельности современного специалиста. Иностранный язык в вузе способствует развитию коммуникативной, информационной, социокультурной и остальных компетенций. Знание иностранных языков позволяет современному человеку продолжать совершенствовать полученный в высшем учебном заведении опыт на протяжении всей жизни, что предусматривает профессиональный и культурный рост человека, активность его жизненной позиции. Подготовка филологов-лингвистов в системе высшего профессионального образования должна способствовать формированию у них таких способностей, которые дадут им возможность использовать иностранный язык в качестве инструмента общения в диалоге культур в своей профессиональной деятельности. В XXI в. иностранные языки являются необходимым для каждого специалиста инструментом, владение которым обеспечивает ему вхождение в профессиональное общество в глобальном, мировом масштабе. Поэтому формирование творческого подхода и профессиональной компетенции как базовых навыков приобретает особую актуальность и значимость в образовательном пространстве языкового вуза.

Современная учебная парадигма выводит на первый план профессиональной подготовки будущего преподавателя иностранного языка формирование межкультурной компетенции как способности коммуникативной личности актуализировать себя в рамках диалога культур. Контекстуальная база языкового образования должна способствовать формированию человека культуры, который способен интегрироваться в мировое сообщество, представлять себя как интеллектуально-развитую и образованную личность и функционировать в языковой среде [4, с. 152]. Доминантой становится познавательная деятельность человека как механизм оптимизации процесса получения, анализа и обработки информации. 


\section{Pasynok Valentyna}

Познавательная деятельность представляется единством четырех взаимосвязанных компонентов: образовательного (понимание культуры, оформление собственных мыслей), развивающего (развитие коммуникативных и ценностных ориентаций), воспитательного (толерантность к другой системе ценностей) и практического (использование языка как механизма эффективного общения). Все эти компонеты являются ингеренными частями нового научного направления в языкознании, которое сформировалось на пересечении социального, психологоческого и философского направлений - эколингвистики.

\section{2. Эколингвистика и ее связь с риторикой, стилистикой и культурой речи}

Эколингвистика занимается выявлением законов, принципов и правил, общих как для экологии, так и для языка, и исследует роль языка в возможном решении проблем окружающей среды. Эколингвистика стремится к очищению окружающей среды языковыми средствами. Мудрое человеческое слово способно обратить много в интересах всего человечества. Термин «языковая экология» выступает за чистый язык. Появилось даже понятие - «экология речевой среды», то есть это то, что нуждается в защите. Слово «экология» состоит из двух греческих слов: oikos и logos. Предметом лингвоэкологии естькультура мышления и речевого поведения, воспитание лингвистического вкуса, защита литературного языка.

Риторика, стилистика и культура речи связаны с проблемой нормирования национальных литературных языков: в их сегодняшнюю интерпретацию включается нормативный компонент, этический компонент (этика общения) и коммуникативный компонент, под которым понимается не только правильное использование языка, но и речевое мастерство. Все эти три стороны культуры речи, особенно последняя, тесно переплетаются с задачами вышеупомянутых дисциплин, в частности с чистотой и правильностью речи. Именно эти аспекты рассматриваются эколингвистикой, изучающей функции языка, которые не исчерпываются простым обменом речевыми актами. Эколингвистика исследует роль языка как инструмента поддержки общности, функционирование этого инструмента в конкретных ситуациях общения. Помогая осознать механизмы обострения конфликтов и возникновения вопросов, эколингвистика пытается способствовать мирному 


\section{Ecolinguistic approach to the training of students-philologists}

сосуществованию людей в различных социальных группах и в обществе [5, с. 39].

Учеными выделяется микро - и макро уровни в эколингвистике. Разница микро- и макро эколингвистики носит относительный характер, и пограничная черта между ними будет весьма неопределенной [6, с. 164]. Макроэколингвистика сосредотачивает основное внимание на вопросах общественной, государственной, региональной и мировой значимости. Микроэколингвистика выдвигает на первый план исследования языковых и речевых фактов с учетом факторов эколингвистического порядка и привлечения концептуальных аспектов теории языковых контактов, социолингвистики, психолингвистики, социокультурной антропологии [7, с. 66]. В эколингвистике дифференцируются два направления: «экологическая лингвистика», которая «отталкивается» от экологии и метафорически переносит на язык и языкознание экологические термины и «языковая экология», которая рассматривает выражение в языке экологических тем, опираясь на языкознание и его методы.

Одним из важнейших критериев экологичности языковых единич является их соотнесенность с антропоцентризмом, который проявляется в языковой номинации явлений действительности, рассмотрении их с точки зрения полезности и бесполезности для человека. Аспектами лингвоекологии являются:

1) транслингвальный (связанный с использованием единиц, средств, реалий одного языка, одной культуры в контексте и сравнении других языков принадлежит другой культуре в художественной литературе, публицистике)

2) интерлингвальный (связанный с полиречью как со сферой среды отдельных этнических языков и с проблемой исчезновения языков, а потому с изменением лингвистического разнообразия на Земле);

3) интралингвальный (связанный с культурой речи, стилистикой, риторикой и включает исследования нарушений правильности, ясности, логичности, выразительности и других коммуникативных свойств речи). Именно этот подход рассматривается в работе.

Эколингвистика исследует нарушения норм правильности, ясности, логичности, четкости, выразительности и других коммуникативных свойств речи. Нарушение норм было предметом анализа в классической риторике, которая занималась изучением непонятных мест, 


\section{Pasynok Valentyna}

объяснялись прежде всего, непонятные слова с помощью их перевода на современный язык (голоса), кроме того, предоставлялись реальные комментарии к тексту (схоли). Норма в языке - это ее общепринятая, узаконенная, единица. Нормативность в речи проявляется в соблюдении норм языка [5, с. 39]. Стилистическая норма является функциональным явлением, которое становится речевой реальностью только при условии, что говорящие: а) подбирают и используют языковые единицы, свойственные литературному языку; б) употребляют слова и фразеологизмы с закрепленной за ними семантикой; в) коммуникативные единицы языка, особенно предложения; г) соблюдают требования определенного стиля речи. Без этого речь является неестественной, следовательно, и стилистически ненормативной [там же]. Но следует осознавать, что в природе и культуре речи, в частности сформировались и функционируют независимо от воли отдельного человека (общественное сознание знания языка, речевая культура), явления субъективные, которые творятся отдельной личностью и служат показателями его индивидуальности.

Коммуникативный компонент культуры речи опирается на коммуникативную стилистику, которая рекомендует наиболее соответствующий сфере и условиям речевой коммуникации выбор языковых средств, и связана непосредственно с речевым мастерством, то есть риторика, как и культура речи, также взаимодействует со стилистикой. С коммуникативной стилистикой риторику соединяет прагматический подход к языку [8, с. 84-89]. Риторическое построение предстает как методика использования имеющихся языковых средств для выражения мысли и как обоснование предложенных ритором идей. Так, во французской риторике серьезное внимание уделяется чистоте речи, технике речи, манерам оратора, жестикуляции, мимике. Формируется светская риторика: риторика беседы, эпистолярная риторика, риторика портрета, риторика загадки и т. д. С искусства речи риторика превращается в целый жизненный кодекс [9, с. 35]. Как и во многих других европейских странах, во Франции доминирует духовное красноречие. Рядом с сухим философом появляется красноречивый оратор, обладающий изысканным вкусом и литературной формой.

Во французской риторике прежде всего, четко противопоставляются такие взаимосвязанные понятия, как звучность / неблагозвучность, краткость / широта, асхематизм / схематизм,однообразие / 


\section{Ecolinguistic approach to the training of students-philologists}

разнообразие, логичность / алогичность, правдоподобие / неправдоподобие, ясность / неясность, точность / неточность, однозначность / двусмысленность, уместность / неуместность и т.д.

Французские ученые - Г. Дессон и Х. Месхоник [10] рассматривают принципы акустического милозвучия и его нарушения. Г. Сериани изучает девиации ритма («вариативность сильных и слабых мест») [11]. Противоречия между лаконичностью и обширностью обнаруживает М. Магниен [12]. Эллипсис представлен в работе Ф. Санктиуса [13, с. 94-98]. Так называемый «рубленый стиль», что создает бессоюзие, рассматривался Л. Спитцером [14]. Противопоставлением гиперболы и литоты занимается П. Фонтанье, который акцентирует внимание на дискурсивных несоответствиях содержания действительности текущих дел [13]. Французские поэты Гиийом Апполинера и Пьер Риверди отмечают, что фигурные тексты вносят в литературу посторонний элемент, что приводит к трудностям при прочтении [15].

Так что проблемы эколингвистики уже давно волнуют ученых. Эколингвистика акцентирует внимание на нарушении литературных норм говорящими, что вызывает у знатоков ощущение дисгармонии, угловатости. Именно риторика, стилистика а также культура речи «следят» за тем, чтобы вещание было нормативным, чтобы говорящие придерживались фонетических, морфемно-стилистических, орфографических и других норм. Культура речи является степенью совершенства, достигнутого в овладении устной и письменной речью, высоким уровнем языковой мастерства, который предполагает овладение и умение использовать выразительные средства в разных условиях общения в соответствии с целями [16].

Современная концепция культуры речи как объекта эколингвистики включает в себя четыре компонента:

1. Языковой компонент, для которого действует оценочная оппозиция: правильно - неправильно.

2. Коммуникативный компонент - это учет ситуации общения и фактора адресата. Хорошая речь - это, прежде всего, речь целесообразная. Любое высказывание не может оцениваться вне ситуативного контекста. Для этого компонента культуры речи действует оценочная оппозиция: уместно-неуместно, понятно - непонятно.

3. Эстетический компонент подразумевает, что речь должна вызвать у слушателя чувство эстетического удовлетворения. Для этого компо- 


\section{Pasynok Valentyna}

нента культуры речи действует оценочная оппозиция красиво - некрасиво, выразительно - невнятно.

4. Этический компонент культуры речи определяет выбор языковых и речевых средств с учетом морального кодекса и культурных традиций (соблюдение речевого этикета, уместность речи). Для этого компонента культуры речи действует оценочная оппозиция: приемлемо - неприемлемо, прилично - неприлично [17, с. 26]. Этический компонент культуры речи требует такого уровня разговора, при котором чувства собеседников не будут затронуты или унижены. Это касается формы обращения к ним - полным или сокращеннымименем, на «ты» или на «вы», это способ приветствия и прощания, выражения просьбы или благодарности. Этический аспект культуры речи зависит от возраста и статуса людей, их взаимоотношений. Он влияет и на тему разговора и его содержание. Например, под запретом должны быть сквернословие, грубость, разговоры на повышенных тонах. Всегда помня о культуре речи и учитывая ее три важные аспекты, можно сделать свое общение правильным и эффективным. Слушателю будет понятно и интересно все, что вы говорите, и общение с вами будет полезным и запоминающимся [там же].

Языковой, коммуникативный, этический и эстетический компоненты культуры речи формируют компетентность студента-филолога.

\section{3. Комуникативная компетентность как экологическое качество студента-филолога}

Компетентность (от лат. competens - соответствующий) - это: 1) знания, опыт в той или иной области; 2) область полномочий управляющего органа, должностного лица; круг вопросов, по которым они обладают правом принятия решений. Особенно важен профессиональный аспект - осмысление профессиональной среды, осознанное выстраивание отношений с окружающими людьми. Этим и определяется существенная роль высшего образования в формировании коммуникативной компетентности [18, с. 104]. Энциклопедический словарь под ред. проф. А.А. Бодалева определяет коммуникативную компетентность как «владение сложными коммуникативными навыками и умениями, формирование адекватных умений в новых социальных структурах, знание культурных норм и ограничений в общении, знание обычаев, традиций, этикета в сфере общения, соблюдение приличий, воспитанность, ориентация в коммуникативных средствах, присущих 


\section{Ecolinguistic approach to the training of students-philologists}

национальному, сословному менталитету и выражающихся в рамках данной профессии. Коммуникативная компетентность - это обобщающее коммуникативное свойство личности, включающее в себя коммуникативные способности, знания, умения и навыки, чувственный и социальный опыт в сфере делового общения» [19, с. 254].

Коммуникативная компетенция включает в себя: 1) языковую компетенцию - знания об изучаемом языке по его уровням: фонетику, лексику, состав слова и словообразование, морфологию, синтаксис простого и сложного предложения, основы стилистики текста; умение пользоваться всеми единицами и средствами языка в соответствии с его нормами; 2) речевую компетенцию - знания о способах формирования и формулирования мыслей посредством языка и умение пользоваться такими способами в процессе восприятия и порождения речи; 3) дискурсивную компетенцию - знания об особенностях протекания речевого события и умения управлять им; 4) культуроведческую компетенцию - осознание языка как формы выражения национальной культуры, знания о взаимосвязи языка и истории народа, о национально-культурной специфике языка; владение нормами речевого этикета, культурой межнационального общения; умения учитывать эти сведения в процессе общения и корректировать своё речевое поведение в соответствии с нормами социального поведения, присущими данному этносу; 5) риторическую компетенцию - знания о риторических моделях создания текстов и способность осознанно создавать, произносить и рефлексировать авторско-адресный текст риторического жанра в соответствии с целью и ситуацией [12, с. 108-109].

Высшая степень проявления коммуникативной компетентности состоит в готовности студента-филолога использовать сформированные у него знания, умения, способы деятельности для организации информационной среды с целью разрешения проблемных ситуаций, в которых он заинтересован. Для этого должны быть выражены определённые качества, черты гуманистической направленности; коммуникативные знания, умения и коммуникативная техника (когнитивная, аффективная, регулятивная); готовность к реализации коммуникативных знаний, умений и навыков в сфере профессиональной деятельности и желание осуществлять эту готовность [там же].

О.Н. Новикова выделяет три базовые составляющие коммуникативной компетенции студента: знания (включающие основы комму- 


\section{Pasynok Valentyna}

никации в определенной культуре), умения (войти в разговор, поддержать коммуникацию, выйти из разговора), креативность навыков (чтение, письмо, аудирование, говорение), интерактивность (компетентно- стный подход предполагает наличие не только теоретических, но и практических знаний, возможность освоения и внедрения новых технологий) [цит. за 20, с. 147]. Уровень овладения коммуникативной компетенцией определяется этапом и целью обучения. В.И. Тесленко и С.В. Латынцев выделяют четыре уровня сформированности коммуникативной компетенции: 1) базовый уровень - преобладают заучивание, репродуктивный уровень заданий; 2) оптимально-адаптивный - студенты не владеют в достаточной мере всеми составляющими коммуникативной компетенции, но при этом демонстрируют готовность к ее проявлению (хотя нерегулярно) и обладают заметным потенциалом; 3) творческо-поисковый - студенты демонстрируют достаточное развитие коммуникативной компетенции, успешно действуют в проблемных ситуациях, готовы к адаптации в информационной среде [21, c. 25].

Названные уровни могут быть соотнесены с уровнями усвоения знаний, описанными В.П. Беспалько: 1) деятельность по узнаванию (ученический уровень) - правильное выполнение заданий; 2) деятельность по решению типовых задач (алгоритмический уровень) - полнота и действенность; 3) деятельность, связанная с выбором действия (эвристический уровень) - выполнение мыслительных операций; 4) деятельность по поиску решения (творческий уровень) - опора на жизненный опыт, работа воображения и активное мышление [22, с. 84].

Конечно, коммуникативная компетентность, как и любая другая компетентность, - сложное явление, подразумевающее не только владение студентами различными знаниями, умениями и навыками, но и способность использовать имеющийся речевой опыт для решения новых проблем. Система высшего образования существует, в основном, за счет внутренних ресурсов, основным из которых является предметное обучение. Именно изложение студентам определенного объема информации превалирует в системе высшего образования. Следованию компетентностной парадигме зачастую мешает отсутствие необходимых учебных программ, методов обучения [23, с. 104-105].

К сожалению, в настоящее время многие студенты языковых вузов не обладают достаточно развитой коммуникативной компетентно- 


\section{Ecolinguistic approach to the training of students-philologists}

стью. Между тем, студент-филолог - это потенциальный преподаватель, и наибольшие трудности при решении профессиональных задач преподаватели испытывают, сталкиваясь с проблемами коммуникативного характера - такими, как выбор адекватных средств передачи информации, правильная аргументация своей позиции и др. Поэтому коммуникативная компетентность студентов языковых вузов может рассматриваться как основа их профессионализации.

Среди личных качеств, которые влияют на успешность карьеры молодых специалистов, выделяют свойства аргументировать свою мысль, способности к общению, к самореализации и совершенствованию. Основной формой активности сформировавшейся личности является профессиональная деятельность, эффективность которой во многом зависит от ее творческого характера. В этой связи особую значимость приобретает процесс развития креативности. «В современном обществе креативные качества личности должны выходить на первый план (это, прежде всего, активность на занятиях, продуктивное решение поставленных преподавателем задач, интуиция, способность привносить нечто новое в учебное занятие, порождать оригинальные идеи, улавливать противоречия, формулировать гипотезы, а, главное, - развивать способность отказываться от стереотипных способов мышления)» [24, с. 53-56]. А.И. Кочетов выделяет следующие качества творческих студентов: любознательность, увлеченность, сообразительность, объективность, прогностичность, инновационность, эмоциальная восприимчивость, развитая фантазия, требовательность к себе [там же]. Креативность также непосредственно связана с интеллектуальными способностями [25, с. 20-21]. Описание креативности как универсальной способности личности к творчеству требует его соотнесения с определенными подструктурами личности, определения ведущего отношения личности к окружающему миру и к самому себе, выделения показателей и критериев сформированности данного качества.

Все вышеуказанные качества в той или иной степени подразумевают деятельность студента и преподавателя, которая получает новый импульс, обретая новые ценности и смыслы. Общение проблематизируется, преподаватель-инноватор освобождается от авторитарного стиля общения, вовлекая в процесс со-творчества своих единомышленников и оппонентов. В этих условиях формируется продуктивная личность 


\section{Pasynok Valentyna}

педагога и учащегося в атмосфере диалога-общения, диалога-взаиморегуляции [2, с. 128-129]. Таким образом, высшая школа сегодняшнего дня создает предпосылки для объединения усилий работников сферы образования на подготовку специалистов, которые могли бы достойно представлять нашу страну в международных профессиональных сообществах. Возникает интерактивное взаимодействие преподавателя и студента, предполагающее дивергентное развитие, ведущее к формированию коммуникативной и творческой компетентности личности, которая является важнейшей составляющей профессионализма.

Рассмотрим способы формирования правильной, экологически наполненнойкомпетентности на примере аспекта «Домашнее чтение» при обучении французскому языку.

\section{4. Инновационные аспекты как эко-механизм обучения домашнему чтению}

Осваивая французский язык, в ВУЗе значительное внимание уделяется чтению, в частности, аспекту «Домашнее чтение»; студенты выбирают аутентичные произведения различной функциональной направленности, что способствует получению информации о культуре, реалиях и особенностях изучаемой страны, а также расширяет и формирует коммуникативные компетенции учащихся.

Чтение литературы - один из способов знакомства с другим народом, его культурой. В современной трактовке чтение - это специфическая форма языкового общения людей посредством печатных или рукописных текстов, одна из основных форм опосредованной коммуникации [26, с. 241]. Художественное произведение - носитель и источник информации о мире, в котором отражаются элементы реальности, это зеркало жизни и культуры народов [27]. Чтение аутентичных текстов дает возможность студенту почувствовать атмосферу того времени, которое описывается в произведении.

Домашнее чтение как один из аспектов языковой подготовки студента обеспечивает более прочное формирование различных видов коммуникативной компетенции (лингвистической, социолингвистической, дискурсивной, социокультурной) [28, с. 95]. Так, Н.А. Селиванова выделяет такие функции аспекта домашнего чтения: 1) культурно-созидательную - обеспечивает сохранение, передачу и развитие общеобразовательной культуры средствами литературно-художественного 


\section{Ecolinguistic approach to the training of students-philologists}

компонента; 2) развивающую - формирование самостоятельного эстетического отношения к окружающему миру, критического, творческого мышления; 3) обучающую - формирование умений так называемого интеллектуального и компетентного чтения, соотнесение содержания произведения со своим личным опытом [29]. Одной из основных функций обращения к аспекту «Домашнее чтение» является аксиологическая, способствующая нравственному и духовному развитию будущего специалиста, расширению системы ценностных ориентаций, формированию педагога, обладающего высокой нравственной культурой, способного решать профессиональные задачи, руководствуясь гуманистическими идеалами и принципами. Учитывая функциональную направленность аспекта «Домашеее чтение», считаем обязательным для студентов постоянное и обильное чтение художественной литературы с целью извлечения содержательной информации. По характеру понимания и интерпретации читаемого - это синтетическое и аналитическое чтение: языковая форма текстов требует от читающего достаточных когнитивных усилий для ее раскрытия, и основное внимание читающего направлено на извлечение текстовой информации. По способу чтения это чтение про себя или в идеальном виде - визуальное чтение «как наиболее совершенное и зрелое» [30, с. 124].

Опыт показывает, что успешное обучение чтению на иностранном языке возможно при определенных условиях: 1) сформированность у учащихся навыков устной речи и навыков чтения; 2) знание учащимися предмета, о котором идет речь в тексте; 3) доступность текста для понимания в языковом отношении; 4) осознание учащимися практической необходимости выполнения самостоятельной рецептивной деятельности; 5) наличие ориентирующей задачи (установки) на выполнение деятельности [31, с. 101]. Как было отмечено выше, основной ориентирующей задачей является аксиологичность аспекта «Домашнее чтение». Преподавание в таком случае должно представлять собой совокупность педагогической и методической стратегий, которые направлены на ценностное развитие будущих специалистов и их нравственные, а также духовные характеристики при ознакомлении с литературой изучаемой страны. Методика реализации аксиологического подхода на интегрированных занятиях по французскому языку в аспекте «Домашнее чтение» характеризуется последовательностью этапов работы с тем или иным художественным произведением. Например, Н.А. Коваленко 


\section{Pasynok Valentyna}

и А.Ю. Смирнова делят изучаемые тексты для анализа на три части: дотекст, текст, послетекст [28, с. 91-97]. Дотекст - фаза ориентировки планирования. Общая ориентировка по тексту должна обеспечить коммуникативно-познавательную потребность, а именно: извлечь содержательно-концептуальную информацию [там же]. Во время второй фазы студенты должны уметь 1) анализировать различные аспекты текста с целью его понимания; 2) выделять микротемы; 3) находить главную и вспомогательную информацию с опорой на знания о строении текста, шрифтовое / графическое оформление сообщения; 4) осуществлять компрессию текста путем исключения, обобщения, свертывания содержащейся в тексте информации [31, с. 57-59]. Третья фаза (послетекстовая) является контрольной. На этом этапе обучаемые должны уметь отражать обобщенную информацию сообщения, ставить вопросы к тексту, пересказывать текст и т. д. [там же].

Такое разделение соотносится с развивающимся современным подходом к работе с художественным произведением по аспекту «Домашнее чтение», хотя он есть более детальным и расширенным. Он включает: этап экспозиции, аналитико-оценочный этап, аналитико-лингвистический этап, этап творческой интерпретации [там же].

На этапе экспозиции происходит погружение в определенную культурно-историческую эпоху и создание эмоционального тона занятия, что является крайне важным именно для ознакомления с художественным произведением.

Аналитико-оценочный этап характеризуется обсуждением проблем, поднятых в прочитанных аутентичных текстах, что помогает сформировать ценностные отношения и ценностные суждения. Студентам рекомендуются следующие задания по аспекту «Домашнее чтение»: 1) представить поведение персонажей в других ситуациях (например, несколько лет спустя); 2) от лица различных персонажей пересказать текст; 3) задать свои вопросы к героям, если бы была такая возможность; 4) придумать аннотацию к книге; 5) написать письмо герою/героине книги; 6) предложить совет герою/героине; 7) рассказать о своем любимом персонаже. Одним из распространенных заданий является составление пересказа текста.

Аналитико-лингвистический этап направлен на формирование лексических, грамматических навыков, совершенствование речевых навыков, развитие монологической и диалогической речи. На данном 


\section{Ecolinguistic approach to the training of students-philologists}

этапе очень важным аспектом является интерпретация текста по его лингвистическим признакам, т.е. студенты должны ответить на вопрос «А что скрывают слова?». Так, например, компаративные тропы, основанные на сближении или совмещении двух или нескольких значений в какой-то точке речевой цепи, реализуют на уровне словесного ряда общий принцип построения художественного текста - принцип противопоставления элементов - и, следовательно, как правило, оказываются включенными в сложные композиционные сцепления деталей, мотивов и целых фабульных линий. Поэтому, в ходе интерпретации текста в аспекте «Домашнее чтение» компаративные тропы необходимо рассматривать не как изолированные явления, а как компоненты образной системы произведения, в тесной связи с явлениями других уровней текста, а также друг с другом и с иными средствами словесной изобразительности.

Рассмотрим и проанализируем образные сравнения в рассказе Мопассана «Dans les Champs» [33]:

(1-2) Les deux mères distinguaient à peine leurs produits dans le tas (c. 8).

(3) ... les ménagères réunisaient leurs moiches pour donner la pâtée, comme des gradeurs d'oies assemlent leur bêtes (c. 16-18).

(4) La mère empâtait elle-même le petit (c. 22).

(5) El la jeune femme, radieuse, emporta le marmot hurlant, comme on emporte un bibelot désiré d'un magasin (c. 117-118).

Примеры связаны с детьми: дети, все вместе или поодиночке либо являются темой $(1,2)$, либо входят в состав темы $(3,4,5)$ каждого из этих образных выражений. Наиболее тесно связаны между собой сравнение 4 и метафора 5: оба выражения не только характеризуют процесс подготовки к еде и самой еды, но и в какой-то степени приравнивают детей к домашней птице, подчеркивая тем самым грубо приземленный, почти живой характер повседневного существования крестьян и отсутствие с их стороны всяких сантиментов по отношению к детям.

Еще одним аспектом, на который следует обращать внимание, является уникальный синтаксический рисунок, присущий французским произведениям. Так, в следующем примере множество следующих друг за другом процессных глаголов-сказуемых, соединенных в одной фразе, становится иконическим знаком быстро протекающих и сменяющих друг друга действий, которые, в свою очередь, выступают как характерная деталь - внешнее проявление темперамента героини: 


\section{Pasynok Valentyna}

(6) Et, sautant de la voiture, elle courut aux enfants, prit un des deux derniers, celui des Tuvache, et l'enlevant dans ses bras, elle le baisa passionnément sur ses joues sales, sur ses cheveux blonds frisesés et pommadés de terre, sur ses menottes qu'il agitait pour se débarrasser de caresses ennuyaeuses (c. 36-39) [там же].

В приведенном примере синтаксический рисунок фразы является прежде всего иконическим знаком реально совершающегося «внешнего» действия и лишь затем - восприятия последнего наблюдателем. A, к примеру, в следующем случае синтаксис отражает и изображает особенности протекания только психического процесса - восприятия, мысли или чувства:

(7) Julien remarqua qu'il y avait sur l'autel des cierges qui avaient plus de quinze pieds de haut [34].

Этап творческой интерпретации направлен на развитие оценочной сферы студентов, творческих способностей, говорения, монологической и диалогической подготовленной и неподготовленной речи. Разбор творческой интерпретации текста производим на примере текста Антуана де Сент-Экзюпери «Le Petit Prince»:

(8) Lorsque j'avais six ans j'ai vu, une fois, une magnifique image, dans un livre sur la Forêt Vierge qui s'appelait «Histoires Vécues». Ça représentait un serpent boa qui avalait un fauve. Voilà la copie du dessin. On disait dans le livr: «Les serpents boas avalent leur proie tout entière, sans la mâcher. Ensuite ils ne peuvent plus bouger et ils dorment pendant les six mois de leur digestion.»

J'ai alors beaucoup réfléchi sur les aventures de la jungle et, à mon tour, j'ai réussi, avec un crayon de couleur, à tracer mon premier dessin. Mon dessin numéro 1. Il était comme ça: J'ai montré mon chef-d'œuvre aux grandes personnes et je leur ai demandé si mon dessin leur faisait peur. Elles m'ont répondu: «Pourquoi un chapeau ferait-il peur?» Mon dessin ne représentait pas un chapeau. Il représentait un serpent boa qui digérait un éléphant. J'ai alors dessiné l'intérieur du serpent boa, afin que les grandes personnes puissent comprendre. Elles ont toujours besoin d'explications... [35].

Предлагаем такие виды заданий к этому тексту:

1. Задания, способствующие самостоятельному пониманию новых лексических единиц, встречающихся в тексте:

Cherchez les contraires des mots du texte suivants et employez les dans une phrase de vous-même: 


\section{Ecolinguistic approach to the training of students-philologists}

- Magnifique

- Beaucoup

- Grandes

- Toujours

2. Задания продуктивного характера на формирование собственных высказываний в связи с прочитанным и способности аргументировать свою точку зрения о том или ином явлении реальной жизни в стране изучаемого языка:

- Indiquez une citation qui vous semble importante, intéressante, touchante ou amusante.

- Que pensez-vous sur les aventures de la jungle? Si vous étiez le Petit Prince que dessinez-vous?

3. Написать эссе на тему: «Et vous, si vous deviez être un personnage du petit prince, lequel choisiriez-vous et pourquoi?»

Аспект «Домашнее чтение» на занятиях по французскому языку на основе интеграции иностранного языка, художественной культуры и художественных текстов обладает огромным учебным, познавательным, развивающим и воспитательным потенциалом. Он предполагает разносторонний и многофакторный личностно-ориентированный подход как со стороны студента, так и со стороны преподавателя: навыки и умения извлечения информации из аутентичного текста, использование различных учебных стратегий для глубинного анализа прочитанного, особая технология обучения в форме обучающих заданий, упражнений и приемов контроля.

\section{5. Выводы}

Обобщая вышеизложенное, мы приходим к выводу, что еколингвистика изучает роль языка как инструмента поддержки всеобщности, функционирование этого инструмента в конкретных ситуациях общения. Экологический подход к вопросам культуры речи предполагает ответственное отношение к национальным языковым традициям, воспитание любви к родному языку, забота о ее прошлом, настоящем и будущем. В этом важную роль играют совместные с ней дисциплины - стилистика и риторика. Риторические и стилистические аспекты в русле эколингвистике представляются очень актуальными и перспективными с точки зрения нормы любой речевой деятельности. 


\section{Pasynok Valentyna}

\section{Список литературы:}

1. Седов К. Ф. Речежанровая идентичность и социализация личности / К.Ф. Седов // Известия Саратовского университета. Новая серия. Серия Философия. Психология. Педагогика. - 2009. - Т. 9. - №. 4. - С. 56-58.

2. Самохина В. А. Современная англоязычная шутка: [монография] / В. А. Самохина. - Харьков : ХНУ им. В. Н. Каразина, 2013. - 356 с.

3. Кан-Калик, В.А. О педагогическом общении [Текст] / В. А. Кан-Калик, Г. А. Ковалев // Вопросы психологии. 1985. - № 4. - С. 9-16.

4. Самостоятельность студентов как фактор успешности в будущей профессиональной деятельности / Ю.А. Ахметова., С.Ю. Кузьмин, Д.А. Мустафина // Успехи современного естесствознания. - 2011. № 8. - С. 152-153.

5. Дудик П.С. Стилістика української мови / П.С. Дудик // Навч.пос. Київ: Вид. центр «Академія». - 2005. - 368 с.

6. Shriberg E. To 'errrr' is human : ecology and acoustics of speech disfluencies / Elizabeth Shriberg // The Journal of the International Phonetic Association. - 2001. 31 (1). - P. 153-169.

7. Жуковська В. В. Еколінгвістика : становлення та основні напрями досліджень / В. В. Жуковська, Н. О. Деркач // Науковий вісник Волинського національного університету імені Лесі Українки. Серія «Філологічні науки. Мовознавство». - 2011. - № 2. - Ч. 1. - С. 66-70.

8. Ионова С. В. Основные направленя эколингвистических исследований: зарубежный и отечественный опыт / С. В. Ионова // Вестник Волгоградского государственного университета. Серия 2. «Языкознание». - 2010. № 1 (11). - C. 86-93.

9. Кравченко А. В. Язык и восприятие : когнитивные аспекты языковой категоризации / А. В. Кравченко. - Иркутск : Издательство Иркутского университета, 1996. - $160 \mathrm{c.}$

10. Dessons G., Meschonnic H. Traite du rhythme des verses des proses. Paris, 1998. -364 p.

11. Ceriani G. L'empreinte rythmique // Cahiers de Semiotique Textuelle. № 14. - Nanterre, 1998. - 236 p.

12. Magnien M. L'ellipse a la Renaissance // Ellipses, Blancs, Silences. - Univ. de Pau, 1992. - 315 p.

13. Sanctius F. Minerve ou les causes de la langue latine / Trad. et ed. G. Clerico. Presses Univ. de Lille, 1982. -232 p.

14. Spitzer L. Etudes de style. - Paris, 1970. - 149 p.

15. Reverdy P. Nord-Sud, Self-defence et autres ecrits sur l'art et la poesie. Paris, 1975. $-541 \mathrm{p}$.

16. Atherton J. Language Codes [Electronic resource] / James Atherton. 2013. - Access :http://www.doceo.co.uk/background/language_codes.htm.

17. Роль человеческого фактора в языке : язык и картина мира / [Серебренников Б. А., Кубрякова Е. С., Постовалова В. И. и др.] ; под ред. Б. А. Серебренникова. - М. : Наука, 1988. - 216 с.

18. Дружинин В.Н. Психология общих способностей / В.Н. Дружинин. M., 1995. $-413 \mathrm{c}$. 


\section{Ecolinguistic approach to the training of students-philologists}

19. Бодалев А. В. Психология общения. Энциклопедический словарь под ред. А. Бодалева / А. В. Бодалев - М.: Когито-центр, 2011. - 2280 с.

20. Петровская Л.А. Общение - компетентность - тренинг / Л.А. Петровская // Избр. тр. - М.: Смысл, 2007.-251 с.

21. Тесленко В.И. Коммуникативная компетентность: формирование, развитие, оценивание: монография / В.И. Тесленко, С.В. Латынцев; Краснояр. гос. пед. ун-т им. В.П. Астафьева. - Красноярск, 2007. - 342 с.

22. Беспалько В.П. Слагаемые педагогической технологии / В.П. Беспалько. - М., 1989.- 241 с.

23. Дружинин В.Н. Когнитивные способности / В.Н. Дружинин. - М., 2001. -224 c.

24. Кочетов А.И. Педагогическая диагностика / А.И. Кочетов.- Армавир, 1998.- 287c.

25. Холодная М.Л. Психология интеллекта: парадоксы исследования. Томск: Изд-во Томск.ун-та.- Москва: Изд-во «Барс», 1997.- 224 с.

26. Пассов Е. И. Концепция коммуникативного иноязычного образования (теория и ее реализация). Метод. пособие для русистов / Е. И. Пассов, Л. В. Кибирева, Э. Колларова. - СПб. : Златоуст, 2007. - 200 с.

27. Діброва О.В. Актуальні проблеми домашнього читання у мовному вузі / O.В. Діброва // Web-peсурс науково-практичних конференцій. Електронний pecypc : Режим доступу: http://www.confcontact.com/2009fi 1/3_dibrova.php

28. Домашнеечтениекакважныйкомпонент содержания обучения иностранным языкам в вузе / Н.А. Коваленко, А.Ю. Смирнова // Фундаментальные вопросы теории и практики преподавания. - Тамбов: Грамота, 2015. № 1. - С. 91-97.

29. Домашнее чтение - важный компонент содержания обучения иностранным языкам в средней школе / Н.А. Селиванова // Иностр. яз. в школе. 2004. - № 4. - С. 21-26.

30. Щукин А. Н. Обучение иностранным языкам: Теория и практика : учебное пособие [для преподавателей и студентов] / Анатолий Николаевич Щукин. - М. : Филоматис, 2014. - 416 с.

31. Миньяр-Белоручев Р. К. Методика обучения французскому языку : [учеб. пособие для студентов пед. ин-тов по спец. «Иностр. яз.»] / Рюрик Константинович Миньяр-Белоручев - М. : Просвещение, 2013. - 224 с.

32. O’Malley. M. Language Learner and Learning Strategies / M. O’Malley, A.U. Chamot //Implicit and Explicit Learning of Languages. A book of readings ed. by M.G. Ellis. London: Academic Press, 1994. - P. 43-51.

33. https://books.google.com.ua/books?id=qEfuBQAAQBAJ\&pg=PA484\& lpg=PA484\&dq $=$ La + mère + empâtait + ellemême + le + petit\&source $=$ bl\&ots $=$ oeSHcL WYRi\&sig=upb7HsaWammZbFDUk47NDQ70sas\&hl=uk\&sa=X\&ved=0ahUKE wiQi8j_1KrWAhUrLZoKHfFQACgQ6AEILjAB

34. https://books.google.com.ua/books?id=dTMhCwAAQBAJ\&pg=PA153\& lpg=PA153\&dq=Julien+remarqua + qu'il + y + avait + sur + l'autel + des + cierges + qui + avaient + plus + de + quinze + pieds + de + haut\&source $=$ bl\&ots $=$ HnP 5h3_WD\&sig $=$ JwCuTUnfSPNkpJMWEv4uN9nRrLU\&hl=uk\&sa=X\&ved=0ahUKËwi moCIv 77WAhUJQpoKHTqaAn8Q6AEILjAB\#v=onepage\&q=Julien\%20remarqua\%20 


\section{Pasynok Valentyna}

qu $\%$ E2\%80\%99il\%20y\%20avait\%20sur\%201\%E2\%80\%99autel $\% 20$ des $\% 20$ cierges $\% 20$ qui $\% 20$ avaient $\% 20$ plus $\% 20$ de $\% 20$ quinze $\% 20$ pieds $\% 20$ de $\% 20$ haut\&f=false

35. Antoine de Saint-Exupéry Le Petit Prince [Ressource électronique]. Edition du groupe «Ebooks libres etgratuits» [site]. - Régime d'accès: http://www. cmls.polytechnique.fr/perso/tringali/documents/ st_exupery_le_petit_prince.pdf 14.http://www.itinerairesdecitoyennete.org/journees/dd/index.php?o

\section{References:}

1. Sedov K.F. (2009) Rechezhanrovaya identichnost i sotsializatsiya lichnosti. Izvestiya Saratovskogo universiteta. Novaya seriya. Seriya Filosofiya. Psihologiya. Pedagogika. T. 9. - \#. 4.

2. Samohina, V.A. (2013). Sovremennaya angloyazychnaya shutka. [Modern English-language joke]. HNU im. V. N. Karazina

3. Kan-Kalik, V.A. (1985) O pedagogicheskom obschenii [Tekst] Voprosyi psihologii. \# 4. S. 9-16.

4. Ahmetova Yu.A., Kuzmin S.Yu., Mustafina D.A. (2011) Samostoyatelnost studetnov kak factor uspeshnosti $v$ budushchej professionalnoj deyatelnosti. [Independence of students as the factor of success in future professional activity] Uspekhi sovremennogo estesstvoznaniya.

5. Dudik, P.S. (2005). Stilistika ukrainskoyi movi. [Stylistics of the Ukrainian Language]. Kyiv: Vid. tsentr "Akademia".

6. Shriberg E. To 'errrr' is human : ecology and acoustics of speech disfluencies / Elizabeth Shriberg // The Journal of the International Phonetic Association. 2001. - 31 (1). - P. 153-169.

7. Zhukovska, V.V. (2011). Ecolinguistics: Development and main branches of research Naukoviy visnik Volinskogo natsionalnogo universitetu imeni Lesi Ukrayinki, Seriya Filologichni nauki, Volin, 66-70.

8. Ionova,S.V. (2007). Basic tendencies of ecolinguistic studies: foreign and native experience. Volgograd, 86-93.

9. Kravchenko, A.V. (1996). Yazyik $i$ vospriyatie : kognitivnyie aspekty $i$ yazyikovoy kategorizatsii [Language and perception : cognitive aspects of language category]. Irkitsk: Irkutsk University Publ.

10. Dessons G., Meschonnic H. Traite du rhythme des verses des proses. Paris, 1998. - 364 p.

11. Ceriani G. L'empreinte rythmique // Cahiers de Semiotique Textuelle. № 14. - Nanterre, 1998. - 236 p.

12. Magnien M. L'ellipse a la Renaissance // Ellipses, Blancs, Silences. - Univ. de Pau, 1992. - 315 p.

13. Sanctius F. Minerve ou les causes de la langue latine / Trad. et ed. G. Clerico. Presses Univ. de Lille, 1982. - 232 p.

14. Spitzer L. Etudes de style. - Paris, 1970. - 149 p.

15. Reverdy P. Nord-Sud, Self-defence et autres ecrits sur l'art et la poesie. Paris, 1975. $-541 \mathrm{p}$.

16. Atherton J. Language Codes [Electronic resource] / James Atherton. 2013. - Access :http://www.doceo.co.uk/background/language_codes.htm. 


\section{Ecolinguistic approach to the training of students-philologists}

17. Serebrennikov,B.A., Kubryakova, E. S., Postovalova, V. I. (1988). Rol chelovecheskogo faktora $v$ yazyike: yazyik i kartina mira. [Role of human factor in language - language and world picture]. Moscow : Nauka Publ.

18. DruzhininV.N. (1995) Psihologiya obshchih sposobnostej. [Psychology of general abilities]. Moscow.

19. Bodalev (2011) Psihologiya obshcheniya. Encoklopedicheskij slovar. [Psychology of communication.Encyclopedia Dictionary] Kogito-centr, Moscow.

20. Petrovskaya L.A. (2007) Obshchenie-kompetentnost'-trening. [CommunityCompetence - Training]. Moscow.

21. Teslenko V.I. (2007) Kommunikativnaya kompetentnost': formirovanie, razvitie, ocenivanie: monografiya. [Communicative competence: formation, development, evaluation]. Krasnoyarsk.

22. Bespalko V.P. (1989) Slagaemye pedagogicheskoj tekhnologii [The terms of educational technology]. Moscow.

23. Druzhinin V.N. (2001) Kognitivnye sposobnosti. [Cognitive abilities]. Moscow.

24. Kochetov A.I. (1998) Pedagogicheskaya diagnostika. [Pedagogical diagnostics]. Armavir.

25. Holodnaya M.L. (1997) Psihologiya intellekta: paradoksy issledovaniya. [Intelligence Psychology: paradoxes of research]. Tomsk.

26. Passov E. I. (2014) Kontseptsiya kommunikativnogo inoyazyichnogo obrazovaniya (teoriya i ee realizatsiya). Metodich. posobie dlya rusistov [The Concept of Communicative Foreign Language Education (Theory and its Implementation). Methodology Handbook for the Russians].Saint-Petersbourgh. Zlatoust, 200 p. (in Russian)

27. Dibrova O.V. (2009) AktualnI problemi domashnogo chitannya movnomu vuzI [Actual problems of home reading in the language high school] Available at:: http://www.confcontact.com/ 2009fi 1/3_dibrova.php

28. Kovalenko N.A., Smirnova A.Yu (2015). Domashnee chtenie kak vazhnyiy komponent soderzhaniya obucheniya inostrannyim yazyikam v vuze [Home reading as an important component of teaching foreign languages at a university]. Fundamentalnyie voprosyi teorii i prepodavaniya. Tambov: Gramota, \#1, 91-97 (in Russian)

29. Selivanova N.A. (2004) Domashnee chtenie - vazhnyiy komponent soderzhaniya obucheniya inostrannyim yazyikam $\mathrm{v}$ sredney shkole [Home reading is an important component of teaching foreign languages in high school] / IYaSh. \# 4., 21-26 (in Russian)

30. Schukin A. N. (2014) Obuchenie inostrannyim yazyikam: Teoriya i praktika : uchebnoe posobie dlya prepodavateley i studentov [Teaching foreign languages: Theory and practice: a manual [for teachers and students]. Moscow. Filomatis, 416 p. (in Russian)

31. Minyar-Beloruchev R. K. (2013) Metodika obucheniya frantsuzskomu yazyiku : ucheb. posobie dlya studentov ped. in-tov po spets. "Inostr. yaz." [Methodology of teaching French: study. manual for students ].Moscow. Prosveschenie, 224 p. (in Russian) 


\section{Pasynok Valentyna}

32. O'Malley. M. Language Learner and Learning Strategies /M. O'Malley, A.U. Chamot // Implicit and Explicit Learning of Languages. A book of readings ed. by M.G. Ellis. London: Academic Press, 1994. - P. 43-51.

33. https://books.google.com.ua/books?id=qEfuBQAAQBAJ\&pg=PA484\&lp$\mathrm{g}=\mathrm{PA} 484 \& \mathrm{dq}=\mathrm{La}+$ mère + empâtait + ellemême $+\mathrm{le}+$ petit\&source $=\mathrm{bl} \& \mathrm{ots}=\mathrm{oeSH}-$ $\mathrm{cLWYRi \& sig}=u$ pb7HsaWammZbFDUk47NDQ70sas\&hl=uk\&sa=X\&ved= 0ahUKEwiQi8j_1KrWAhUrLZoKHfFQACgQ6AEILjAB

34. https://books.google.com.ua/books?id=dTMhCwAAQBAJ\&pg=PA153\& lpg=PA153\&dq=Julien+remarqua + qu' $1 \mathrm{il}+\mathrm{y}+$ avait + sur +1 'autel + des + cierges + qui + avaient + plus + de + quinze + pieds + de + haut $\&$ source $=$ bl\&ots $=$ HnP 5h3_WD\& sig=JwCuTUnfSPNkpJMWEv4uN9nRrLU\&hl=uk\&sa $=$ X\&ved $=\overline{0}$ ahUKEwi moCIv77WAhUJQpoKHTqaAn8Q6AEILjAB\#v=onepage\&q=Julien\%20remarqua $\% 20$ qu $\%$ E2\% $80 \% 99$ il $\% 20 y \% 20$ avait $\% 20$ sur $\% 201 \%$ E2\%80\%99autel $\% 20$ des $\% 20$ cierges $\% 20$ qui $\% 20$ avaient $\% 20$ plus $\% 20$ de $\% 20$ quinze $\% 20$ pieds $\% 20$ $\mathrm{de} \% 20$ haut \& $\mathrm{f}=$ false

35. Antoine de Saint-Exupéry Le Petit Prince [Ressource électronique]. Edition du groupe "Ebooks libres etgratuits" [site]. - Régime d'accès: http://www.cmls.polytechnique.fr/perso/tringali/documents/st_exupery_le_petit_ prince.pdf 14.http://www.itinerairesdecitoyennete.org/journees/dd/index.php?o 